\title{
AL-QĀDI $\overline{\mathbf{I}}$ AL-NU'MĀN B. MUHAMMAD AL-MAGHRIBĪ

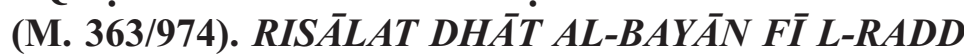 'ALÄ IBN QUTAYBA OU L'ÉPITTRE DE L'ÉLOQUENTE CLARIFICATION CONCERNANT LA RÉFUTATION D'IBN QUTAYBA (I)*
}

\author{
AL-QĀḌ̄ AL-NU'MĀN B. MUḦAMMAD AL-MAGHRIBI

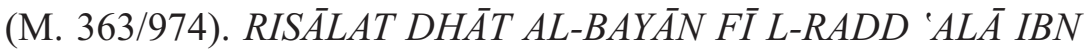 \\ QUTAYBA OR «THE ELOQUENT CLARIFICATION FOR THE \\ REFUTATION OF IBN QUTAYBA» (I)
}

Avraham HaKim

Tel-Aviv University

\begin{abstract}
Al-Qād̄i al-Nưmān b. Muhammad was the most outstanding and prolific Fātimī scholar and the founder of Ismāề1 jurisprudence. In his epistle "The eloquent clarification for the refutation of Ibn Qutayba", still in manuscript, al-Nu'mān engaged in a heated attack on Ibn Qutayba, who had lived a cen-
\end{abstract}

Al-Qādī al-Nưmān b. Muhammad es el más destacado y prolífico de los estudiosos fatimíes y el fundador de la jurisprudencia ismāêlíi. En su epístola "La clarificación elocuente para la refutación de Ibn Qutayba", todavía en manuscrito, al-Nu'mān se lanza a una polémica en contra de Ibn Qutayba, que

\footnotetext{
* La publication de cette contribution sera effectuée en deux parties. La première partie, publiée ici, comprendra une préface générale concernant l'épître, une traduction partielle et une édition annotée de son introduction. La seconde partie, qui sera publiée dans le prochain numéro d'Al-Qantara, comprendra la table détaillée des matières comprises dans l'épître. La présente recherche a pu être effectuée et a été subventionnée grâce à un poste provisoire de chercheur associé, aimablement offert par le Centre National de la Recherche Scientifique (CNRS), Laboratoire d'Etudes sur les Monothéismes (CERL, M. Hoffmann) pendant l'été 2007. Je remercie l'Institut des Recherches Ismaéliennes de Londres (IIS), notamment A. Lalani et M. Daftary, Hussein et Merchant pour leur aide dans l'obtention d'une copie du manuscrit de l'épître. Je dois beaucoup à M.A. Amir-Moezzi (EPHE) pour son assistance et sa bienveillance. Mes remerciements à mon ami et collègue M.A. Chleilat qui a attiré mon attention sur l'épître, m'a fait partager ses vastes connaissances et a mis à ma disposition sa bibliothèque privée. Je voudrais remercier mes collègues les professeurs M.A. Amir-Moezzi, Etan Kohlberg, Maribel Fierro et Bruna Soravia pour leurs remarques et pour leur assistance dans la rédaction de cet article.
} 
tury earlier. The epistle was probably composed in the time of al-Mu'izz at the request of an anonymous tutor of the caliph's sons. Al-Nu'mān's purpose was to refute Ibn Qutayba's assertion in the introduction to his famous Adab al-Kātib, according to which it was enough for the kuttāb, the civil servants of the state, to memorize a number of simple legal formulas in order to perform their duties, without the need to learn the lengthy dissertations of the fuqah $\bar{a}^{\prime}$ or doctors of law. Al-Qāḍi al-Nu'mān, who was himself a famous faqīh, dedicates his epistle to prove that in fact without these long dissertations the law could not be properly applied. He refers to each legal formula mentioned by his opponent in Adab al-Kātib and shows how applications of the law should be based on the authority of the Imāms of the Ahl al-Bayt, the family of the Prophet Muhammad. At the same time he refutes various Sunnite legal perspectives on these same issues.

Key words : al-Qādī al-Nu'mān ; Ibn Qutayba ; Adab al-Kātib; Ismāēìlī Law ; Shī iteSunnite controversy; Maghreb ; al-Mu'izz. había vivido un siglo antes. Es probable que la epístola fuera escrita en la época de alMu'izz a petición de un tutor anónimo de los hijos del califa. En ella, al-Nu'mān se propone refutar la afirmación de Ibn Qutayba, incluida en la introducción de su famosa obra Adab al-Kātib, según la cual era suficiente para la realización de sus tareas que los kuttāb, o funcionarios del estado, memorizaran una serie de fórmulas legales simples, sin tener que aprenderse las largas disertaciones de los fuqaha $\bar{a}^{\prime}$ o doctores de la ley. Al-Qāḍ̄ al-Nu'mān, un faqīh famoso, se dedica en la epístola a demostrar que sin estas disertaciones no se podía aplicar la ley correctamente. En su texto se refiere a cada fórmula legal mencionada por su rival en Adab al-Kätib y demuestra cómo la ley se debería aplicar basándose en la autoridad de los imāmes del Ahl al-Bayt, la Familia del Profeta Muhammad. También refuta las distintas interpretaciones legales sunníes de estas mismas cuestiones.

Palabras clave: al-Qāḍī al-Nưmān; Ibn Qutayba; Adab al-Kātib; ley Ismāêilìi; polémica Šì'í-Sunní; Magreb; al-Mu'izz.

\section{L'introduction de l'épître}

\section{Introduction}

L'Institut ismaélien de Londres conserve dans sa riche collection de manuscrits le manuscrit (Zahid Ali, N. ${ }^{\circ}$ 1164) d'une épître d'alQāḍ̄i al-Nu'mān intitulée Risālat Dhāt al-Bayān fì l-Radd 'alā Ibn Qutayba qu'on a choisi de traduire : L'épître de l'éloquente clarification concernant la réfutation d'Ibn Qutayba. En effet, le terme arabe bayān veut dire « éloquence, surtout faculté d'exposer la chose clairement et avec art ${ }^{1}$, ce que prétend faire l'auteur de cette épître.

Cette épître est bien connue par les biographes anciens ${ }^{2}$ et modernes d'al-Qādị al-Nu'mān, les éditeurs de ses œuvres ${ }^{3}$ et les catalo-

1 Biberstein Kazimirski, A. de, Dictionnaire Arabe Français, Paris, 1860 (Réimpression, Beyrouth, s.d.), s. v. bayān.

${ }^{2}$ Idrīs 'Imād al-Dīn, 'Uyūn al-Akhbār wa-Funūn al-Āthār, M. Ghālib (ed.), Beyrouth, 1996, vol. $6,46$.

3 Fyzee, l'un des grands spécialistes des œuvres de notre auteur, en fait usage et

Al-Qanțara (AQ) XXXI 1, enero-junio 2010, pp. 77-102 ISSN 0211-3589 
gueurs des manuscrits ismaéliens. Cependant, le manuscrit fut mal identifié : on affirme que seule la première moitié de l'œuvre nous est parvenue ${ }^{4}$. On affirme aussi qu'en comparaison avec d'autres manuscrits le nôtre contient seulement les huit premières parties (juz'-ajzā') de l'œuvre 5 . Or le fait est que ce manuscrit contient neuf parties qui constituent donc l'épître entière et pas seulement la première moitié, comme le prouvent les citations suivantes de la fin du manuscrit : Dans la neuvième partie (al-juz' al-tāsi') l'auteur affirme (fol. 86b), après avoir longuement discuté toutes les formules juridiques qu'Ibn Qutayba avait mentionnées dans l'introduction de Adab al-Kātib : Fa-hādhā ākhir al-masā'il allatĩ dhakarahā Ibn Qutayba.

Mais on doit surtout lire la conclusion de l'auteur (fols. 88a-88b) :

Tammati 1-risālatu bi-ḥamdi-Llāhi wa-'awnihi wa-māddati waliyyihi fĩ arḍihi 'alayhi asnā tahiyyātihi wa-salāmihi mā dāma l-falaku fĩ maqāmihi. Wa-lhamdu li-Llāhi Rabbi l-'ālamīna wa-ṣallā-Llāhu 'alā rasūlihi Muhammadin khātami 1-nabiyyina wa-'alā abrāri 'itratihi 1-A'immati l-sādiqīna wa-sallama taslīman. Wa-ḥasbunā-Llāhu wa-ni ma l-wakīlu wa-nì ma l-mawlā wa-nì ma l-nașîru wa-lā hawla wa-lā quwwata illā bi-Llāhi l-'aliyyi l-'azìmi.

Il nous a paru nécessaire de reproduire ici in extenso ces formules finales et traditionnelles pour démontrer que l'épître est en effet complète.

En outre, les catalogues affirment que la réfutation de l'auteur concerne l'œuvre d'Ibn Qutayba intitulée 'Uyūn al-Ma'ārif', ou bien qu'elle concerne «des questions du fiqh ${ }^{7}$. Il semble bien que la

cite plusieurs paragraphes de l'épître dans les notes de bas de page du second volume de son édition des Da'ä'im al-Isläm. Toutefois, Fyzee n'identifie pas le manuscrit auquel il se réfère et ne mentionne pas les feuillets d'après lesquels il cite ses références. Voir al-Qāḍī al-Nu'mān, Da'ā’im al-Islām, A.A.A. Fyzee (ed.), Le Caire, 1951-1969, vol. 2, 27, 32, 43, 72, 83, 87.

4 Poonawala, I.K., Biobibliography of Ismāi ili literature, Malibu, 1977, 63 (n. $\left.{ }^{\circ} 32\right)$; Cortese, D., Arabic Ismaili Manuscripts. The Zāhid 'Alī Collection in the library of the Institute of Ismaili Studies, London, 2003, 156-157 (n. ${ }^{\circ}$ 140). Voir aussi Poonawala, I.K., "Al-Qāḍī al-Nu'mān and Isma ili Jurisprudence", dans F. Daftary (ed.), Medieval Ismāili History and Thought, Cambridge, 2001, 117-143, note 45. Les autres éditeurs des différentes œuvres d'al-Qādī al-Nu 'mān citent généralement la Biobibliography de Poonawala. L'on note que notre épître n'est pas citée dans le catalogue des sources ismaéliennes d'al-Majdū'.

5 Cortese, Arabic Ismaili Manuscripts, 156.

${ }^{6}$ Poonawala, Biobibliography, 63 (n. ${ }^{\circ} 32$ ).

7 Cortese, Arabic Ismaili Manuscripts, 156.

Al-Qanțara (AQ) XXXI 1, enero-junio 2010, pp. 77-102 ISSN 0211-3589 
première assertion confond deux différentes œuvres d'Ibn Qutayba : le Uyūn al-Akhbār d'une part et le Kitāb al-Ma'ārif d'autre part. Quant à la seconde assertion, la lecture de l'épître démontre que la réfutation ne concerne ni le 'Uyūn al-Akhbār ni le Kitāb al-Màārif, bien que ce dernier y soit mentionné, et ne concerne pas simplement «des questions du fiqh». Comme nous pouvons le constater tout au début de l'introduction de l'auteur (fol. 2a), l'épître a pour but de traiter de certaines formules juridiques succinctes mentionnées dans le fameux Adab al-Kātib d'Ibn Qutayba, dont on reparlera plus tard. Lokhandwalla qui publia en 1972 une édition exemplaire avec une introduction critique du Ikhtilāf Ușūl al-Madhāhib (désormais Ușūl) d'al-Qāḍ̄ al-Nu'mān est d'avis que notre épître est une réfutation d'Ibn Qutayba et de son fils Ahmad (m. 321/933) qui fut nommé juge en Egypte en 321/933. De plus il se réfère à Ibn Zūlāq pour énoncer l'hypothèse que notre épître est une réfutation des juristes hanafites. Notre lecture de Dhāt al-Bayān ne confirme aucune de ces hypothèses. Lokhandwalla déclare que cette épître a survécu jusqu'à la première moitié du XVI siècle et il ne semble pas connâ̂tre l'existence de notre manuscrit ${ }^{8}$.

Cortese a fait une description très détaillée du manuscrit ${ }^{9}$, ce qui nous dispense de le faire ici. Nous nous proposons dans cet article de fournir nos arguments concernant le titre Dhāt al-Bayān que choisit al-Qādī al-Nu'mān pour donner un titre à son épître. La date de la composition de l'épître n'étant pas connue, nous essayerons de la situer dans son contexte historique grâce à certaines évidences que l'on trouve dans le texte. Vient ensuite une table des matières détaillée de l'épître qui débute par une analyse détaillée de l'introduction de l'auteur (fols. 2a-8a). Une telle analyse nous permettra d'exposer, entre autre, la polémique de l'auteur contre son antagoniste qui vécut un siècle auparavant ainsi que leurs méthodes de travail et leurs croyances. Puis nous traduirons les formules mentionnées par Ibn Qutayba ${ }^{10}$ et nous résumerons leurs implications

8 Al-Qāḍi al-Nưmān, Kitāb Ikhtilāf Ușūl al-Madhāhib, S.T. Lokhandwalla (ed.), Simla, 1972, 42.

9 Cortese, Arabic Ismaili Manuscripts, 156-157.

${ }^{10}$ Lecomte a traduit en Français des extraits de la préface du Adab al-Kātib, y compris le paragraphe que cite al-Qāḍi al-Nu mān dans son épître, mais il a ignoré les formules juridiques et ne les a pas traduites. Voir Lecomte, G., «L'introduction du Kitāb Adab al-Kātib d'Ibn Qutayba », dans Mélanges Massignon, tome III, Damas, 1957, 60. 
juridiques selon l'analyse d'al-Qādị al-Nu'mān et ainsi que son argumentation. Finalement, nous présenterons en appendice une édition annotée du texte arabe de cette introduction.

\section{Le titre de l'épître}

Nous estimons que le titre Dhāt al-Bayān qu'a choisi al-Qāḍī alNu'mān pour son épître n'a rien de fortuit. L'auteur fait preuve d'une vaste connaissance des sources aussi bien sunnites que shīi ites. Nous pensons que le titre Dhāt al-Bayān proviendrait d'un sermon que 'Alī b. Abì TTālib aurait délivré à la suite de la bataille du Chameau (al-Jamal) (36/656) :

Aujourd'hui, pour vous, je donne la faculté de parler à la muette afin qu'elle possède sens et éloquence. Al-yawm untiq lakum al-'ajmā', dhāt al-bayānn".

Cette phrase fut interprétée dans les sources de la façon suivante :

Al-'ajmā' est celle qui n'a pas la faculté de parler; ceci est une allusion aux symboles que le sermon contient ; il ('Alī) dit : ces symboles sont mystérieux et ambigus mais malgré leurs ambiguité, ils sont évidents pour les initiés (littéralement : « ceux qui sont doués d'intelligence ») comme s'ils parlaient, comme s'ils possédaient une langue (l'organe du parler). Al-'ajmā' allatī lā nutqqa lahā, wa-hādhā ishāra ilāā l-rumūz allatī tatadammanuhā hādhihi i-khuțba; yaqūl : hiya khafiyya ghāmiḍa wa-hiya ma' ghumūdihā jaliyya li-ūlì al-albāb, fa-ka'annahā tanțiq kamā yanțiq dhawū l-alsina ${ }^{12}$.

Nous pouvons indéniablement distinguer dans cette interprétation l'ésotérique et l'exotérique, le bātin et le zāhir qui sont à la base du discours même du crédo ismaélien. A la suite de la lecture

Soravia par contre a fourni une traduction complète de cette préface, y compris notre paragraphe. Voir Soravia, B., “ Ibn Qutayba en al-Andalus. La Préface à l'Adab al-Kātib dans le Commentaire d'Ibn al-Sīd al-Bațalyawsī ", Al-Qantara, XXV (2004), 539-565. Nous avons fait bon usage de ces deux articles dans cette recherche.

${ }^{11}$ Al-Shaykh al-Mufīd, Muhammad b. Muhammad b. al-Nu'mān al-'Ukbarī, al-Irshād fì Ma'rifat Hujaj Allāh 'alā l-'Ibād, Beyrouth, 1993, vol. 1, 207.

${ }^{12}$ Ibn Abīal-Ḥadīd, 'Abd al-Raḥmān, Sharh Nahj al-Balāgha, M. Abū l-Faựl Ibrāhīm (ed.), Beyrouth, 1987, vol. 1, 211.

Al-Qanțara (AQ) XXXI 1, enero-junio 2010, pp. 77-102 ISSN 0211-3589 
approfondie de cette épître, nous émettons l'hypothèse qu'al-Qādī al-Nu'mān aurait intitulé son texte Dhāt al-Bayān tel une symbolique au discours célèbre de 'Alî. Il considère que les formules juridiques succinctes citées par Ibn Qutayba contiennent un bātin qu'il se propose d'élucider pour mettre en relief leur sens exotérique, le zāhir. Dans ce sens il se placerait dans la tradition doctrinale ismaélite qui voudrait élucider pour les lecteurs toutes les ambiguïtés contenues dans le texte ${ }^{13}$. Ibn Qutayba avait précisé dans son introduction de Adab al-Kātib qu'il suffisait que les fonctionnaires maîtrisent « des rudiments de fiqh réduits à la connaissance de formules juridiques élémentaires » pour pouvoir remplir leurs fonctions ${ }^{14}$. En intitulant son épître Dhāt al-Bayān, al-Qādị al-Nu mān semble affirmer que sans son élucidation, ses longues dissertations en matière de législation et sa capacité à faire passer ces formules du bātin au zāhir, il ne serait pas possible d'appliquer la loi comme il se doit, même si les fonctionnaires/les juristes faisaient preuve d'une parfaite connaissance de ces simples formules juridiques. C'est par le titre Dhāt al-Bayān lui-même qu'al-Qāḍi al-Nu'mān débute la réfutation d'Ibn Qutayba. De fait, on peut aller plus loin encore et se demander si le terme Dhāt al-Bayān contient un bătin, une énigme que les initiés seulement peuvent comprendre, et le rapporter au discours de ${ }^{\circ} \mathrm{Al} \overline{1}$, tandis que la seconde partie du titre, fî 1-Radd 'alā Ibn Qutayba, contient le zāhir que chacun peut comprendre.

\section{La date de la composition de l'épître}

Il est clair que la rédaction et la division de l'épître en ajzā' ont été entreprises après la mort de l'auteur. Ainsi, dès le second juz' chacun des chapitres débute par la formule : «chapitre tel et tel du Dhāt al-Bayān composée par al-Qāḍ̄ al-Nu'mān b. Muhammad, que Dieu sanctifie son âme, éclaire sa tombe et nous accorde son intercession » (qaddasa Allāh rūhahu wa-nawwara ḍarịhahu wa-razaqanā shafă'atahu). L'épître n'est pas datée par son auteur, et al-Qāḍī al-

${ }_{13}$ Hamdani, S.A., Between Revolution and State : The Path to Fatimid Statehood, London, 2006 ; surtout les chapitre 2 "From Batin to Zahir", 33-53 et 3 "The Zahiri Framework", 55-92.

${ }^{14}$ Lecomte, G., Ibn Qutayba. L'Homme, Son CEuvre, Ses Idées, Damas, 1965, 445.

Al-Qanțara (AQ) XXXI 1, enero-junio 2010, pp. 77-102 ISSN 0211-3589 
Nu'mān ne la mentionne pas dans ses différentes œuvres, à ma connaissance ${ }^{15}$. Cependant, plusieurs points de repère mentionnés dans les différents chapitres peuvent être signalés. Ces points de repère pourraient, à la rigueur, indiquer, sinon la date exacte, du moins la période approximative à laquelle al-Qāḍi al-Nu mān composa Dhāt al-Bayān. Nous spécifions ici par précaution que nous n'avons étudié qu'un seul manuscrit de l'épître et que si d'autres manuscrits existent nous ne les avons pas à notre disposition. L'auteur réfère le lecteur maintes fois aux ouvrages de fiqh qu'il a déjà rédigés, spécifiant que certains sont longs et détaillés (mabsüt t) tandis que d'autres sont condensés ou abrégés (mukhtasar) ${ }^{16}$. Il serait possible de déduire de cela que notre épître aurait été rédigée après qu'al-Qādī alNu'mān eût terminé de transcrire quelques-unes de ses œuvres juridiques détaillées et ses mukhtașar. Dans ce contexte, Poonawala remarque que lorsque al-Qāọī al-Nu'mān fut nommé au plus haut poste judiciaire de l'état fățimide (durant le règne d'al-Mu'izz, (341365/953-975) il avait déjà à son compte rédigé plusieurs abrégés juridiques en plus de ses grands travaux sur la jurisprudence ismaélite ${ }^{17}$.

Une date plus précise peut être déduite d'après un autre endroit du texte où l'auteur réfère le lecteur à son fameux Ikhtiläf Ușūl alMadhāhib ${ }^{18}$. Il écrit en discutant les différentes opinions juridiques concernant la formule al-bayyina 'alā l-mudda'i wa-l-yaminn 'alā 1 mudda'a 'alayhi (voir plus bas, «Table des matières : première partie ») : «J'ai mentionné ce qui convient concernant l'obéissance qui leur est due (aux Imāms de Ahl al-Bayt) dans le livre Ușūl al-Madhāhib et dans d'autres ouvrages ". Ce livre a été édité avec une introduction critique par S.T. Lokhandwalla. Ce dernier, se référant à des preuves incluses dans le texte, estime que la rédaction de l'Ușūl est postérieure à $343 / 954^{19}$. Si la référence que donne al-Qāḍi al-

15 Dans ses Majālis, al-Qāḍī al-Nu'mān réfute longuement l'interprétation d'une expression coranique d'Ibn Qutayba dans son Ta'wīl Mushkil al-Qur'ān sans pour autant mentionner notre épître. Voir, al-Qāḍī al-Nu'mān, al-Majālis wa-l-Musāyarāt, al-Ḥabīb al-Faqī et al (eds.), Beyrouth, 1997, 147-152.

16 Voir par exemple fols. 55a, 58a, 81b, 82a, 86a.

17 Poonawala, Jurisprudence, 122-123.

18 Fol. 14b.

19 Al-Qādī al-Nu mān, Ușūl, 1972, “Introduction ”, 45. Voir aussi, Poonawala, Jurisprudence, $13 \dot{9}$, note 46 .

Al-Qanțara (AQ) XXXI 1, enero-junio 2010, pp. 77-102 ISSN 0211-3589 
Nu'mān à ce livre n'avait pas été glosée plus tard, lors d'une rédaction ultérieure de Dhāt al-Bayān, il serait donc possible de déduire que notre épître a été rédigée après le Ușül, durant le règne du calife fatimide al-Mu'izz (341-365/953-975). Par conséquent, les fils du calife à qui le livre Adab al-Kātib d'Ibn Qutayba fut inculqué, initiant ainsi la rédaction de notre épître (voir plus bas : «Table des matières : analyse de l'introduction »), seraient les fils d'al-Mu'izz.

Par deux fois al-Qādī al-Nu'mān réfère les lecteurs à un autre de ses ouvrages, al-Ikhtiläf wa-l-Iftirāq qui ne semble pas avoir survécu (à moins qu'il n'ait été soit conservé en manuscrit dans une bibliothèque privée ${ }^{20}$. Ce qui est singulier dans ces deux références c'est qu'elles sont exprimées différemment. En premier lieu (fol. 38 b), alors qu'il fini de discuter des différentes opinions des juristes en ce qui concerne la formule al-za'ìm ghārim (voir plus bas : « Table des matières », 34b-38b) al-Qāḍi al-Nu mān affirme :

J'inscrirai cela et tous les autres sujets juridiques dans le livre al-Ikhtilāf wa-l-Iftirāq s'il plaît à Dieu. Wa-sawfa uthbit dhālika wa-ghayrahu mimmā ya'tī fĩ abwāb al-futyā kullihā fì kitāb al-Ikhtilāf wa-l-Iftirāq in shā'a Allāh).

De là, on peut retenir qu'al-Qāḍī al-Nu'mān se propose de rédiger ce livre, dont il connaît déjà le titre, ou qu'il le rédige parallèlement à la rédaction de notre épître. En second lieu (fol. 57a-57b), à la fin de son exposition des différentes opinions concernant la formule al-bayyi ān bi l-khiyār mā lam yaftariqā (voir plus bas : « Table des matières »", 55b-57b) al-Qādī al-Nu mān écrit :

\footnotetext{
Nous avons inscrit tout cela dans le livre al-Ikhtiläf wa-l-Iftirāq, et ceux qui préfèrent en savoir plus peuvent le chercher dans ce livre et le trouver s'il plaît à Dieu. Wa-athbatnā dhālika kullahu fí kitāb al-Ikhtilāf wa-l-Iftirāq fa-man àthara 'ilm dhālika talabahu fỉhi fa-wajadahu in shā'a Allāh.
}

L'on peut déduire de cette expression que notre auteur aurait terminé la rédaction de cet ouvrage à ce point précis de la rédaction de notre épître, ou au moins qu'il y avait achevé de discuter la formule al-bayyïān bi l-khiyār mā lam yaftariqā. Quoiqu'il en soit, ces deux expressions, si elles n'avaient pas été ajoutées tardivement au

${ }^{20}$ Sur ce livre, voir al-Qāḍ̄ al-Nu'mān, Ușūl, "Introduction ”, 38. Voir aussi Poonawala, Jurisprudence, 139, note 45.

Al-Qanțara (AQ) XXXI 1, enero-junio 2010, pp. 77-102 ISSN 0211-3589 
manuscrit original de l'épître, laissent entendre clairement qu'alIkhtilāf wa-1-Iftirāq fut rédigé et peut être terminé parallèlement à Dhāt al-Bayān. D'après Lokhandwalla, le Kitāb al-Ikhtiläf wa-l-Iftirāq était une large compilation contenant toutes les doctrines légales où al-Qādị al-Nu'mān indiquait sur quels points les juristes sunnites acceptaient ou réfutaient les opinions de Ahl al-Bayt. Plus tard alQāọī al-Nưmān condensa ce livre dans un abrégé intitulé Kitāb alMuqtașar $^{21}$. Or nous savons très peu de choses sur ces livres, mais avec les indications d'al-Qāḍī al-Nu 'mān dans Dhāt al-Bayān il serait possible de conclure qu'al-Ikhtiläf wa-1-Iftirāq et le Muqtașar furent aussi rédigés pendant le règne d'al-Mu'izz, après 343/954.

\section{Table des matières de l'épître}

\subsection{Analyse de l'introduction de l'épître}

Nous diviserons l'analyse de l'introduction d'après les thèmes de la narration d'al-Qāḍi al-Nu'mān.

\subsubsection{Fol. 2a : Le précepteur et les fils du calife}

L'auteur commence son texte par une adresse en style direct en louant un personnage dont l'identité n'est pas connue :

Que Dieu vous comble de félicité pour votre obéissance envers Lui, qu'Il vous engage à faire Son œuvre avec Son contentement, qu'Il vous assiste à votre satisfaction et à celle de Son ami (waliyy, i.e. le calife) et qu'Il vous soutienne dans l'entreprise qu'il (i.e. le calife) vous a confiée et dans la fonction à laquelle il vous a nommé. Vous m'avez fait apporter, que Dieu vous procure le succès, le livre de 'Abd Allāh b. Muslim b. Qutayba qu'il a rédigé au sujet de la lecture correcte, de l'orthographe et de la dérivation (taqwīm al-lisān wa-l-yad wa-lì rāb) ${ }^{22}$, intitulé kitāb Ādāb al-Kuttāb ${ }^{23}$. Vous avez mentionné que vous avez imposé aux seigneurs, les princes, les fils du commandeur des croyants, notre seigneur et maître, de l'étudier en raison des diver-

${ }^{21}$ Al-Qādīi al-Nu mān, Ușūl, “Introduction ”, 38-39. Voir aussi, Poonawala, Jurisprudence, 139 , note 45.

${ }^{22}$ Lecomte, Ibn Qutayba, 106.

${ }^{23}$ Notons qu'al-Qāḍi al-Nu'mān choisit le titre Ādāb al-Kuttāb et non Adab al-Kātib. Par conséquent, il semble que ce titre qui était préféré des Andalous l'était également par les savants du Maghreb. Voir Soravia, "Préface ", 542. 
ses catégories des sciences qu'il contient. Vous leur avez établi son résumé, simplifié les difficultés et ouvert ce qui y était enfermé pour qu'ils le comprennent et prennent connaissance de ce qu'il recèle.

Nous ne savons pas à qui al-Qāḍi al-Nu mān adresse ses louanges dans le premier paragraphe ${ }^{24}$. Il s'avère qu'il s'agit d'une personne chargée d'instruire les fils du calife al-Mu'izz et qui choisit de leur inculquer le Adab al-Kātib d'Ibn Qutayba. Nous notons l'expression d'al-Qādī al-Nu 'mān akhadhta l-umarā' al-sāda wuld amīr al-mu'minīn [...] bi-hifẓihi que nous avons traduite : «Vous avez imposé aux princes, les fils du commandeur des croyants $[\ldots]$ de l'apprendre $»$. Nous retenons que la personne à laquelle l'épître est adressée devait avoir une position suffisamment importante pour pouvoir imposer une matière à étudier aux fils du calife. Il pourrait s'agir d'un précepteur (mu'addib, mu'allim), un kātib haut placé, chargé par le calife d'éduquer ses enfants. Nous ne connaissons pas un tel fonctionnaire dans la hiérarchie fătimide. Plusieurs fonctionnaires auraient pu être candidats à cette fonction et dans l'état actuel de nos connaissances et du fait que nous manquons de sources supplémentaires nous ne pouvons pas identifier ce précepteur.

C'est donc ce précepteur anonyme qui aurait pris l'initiative d'enseigner aux fils du calife le Adab al-Kätib d'Ibn Qutayba après avoir demandé à al-Qādī al-Nu'mān de le lui rapporter de la bibliothèque privée des califes. Al-Qādī al-Nu'mān en avait une connaissance intime puisqu'il fit ses débuts dans l'administration fățimide à amasser et copier des ouvrages pour enrichir cette bibliothèque ${ }^{25}$. Cette riche bibliothèque recélait déjà au temps des premiers califes fātimides une multitude d'ouvrages et l'on mentionne qu'al-Mu'izz était un avide lecteur. Al-Qādī al-Nu'mān raconte l'épisode d'après lequel l'Imām et calife al-Mu'izz relate comment il aurait cherché lui même dans sa bibliothèque un livre pour le consulter, et là, debout, en présence d'une multitude de livres, il oublia ce qu'il vint

${ }^{24} \mathrm{Je}$ voudrais remercier ma collègue Bruna Soravia qui a attiré mon attention sur le problème de l'identification de la personne à laquelle l'épître était adressée. Je remercie aussi messieurs les professeurs Wilferd Madelung et Heinz Halm qui ont bien voulu lire l'introduction de l'épître et formuler leur opinion concernant l'identité de la personne à laquelle qui Dhāt al-Bayān avait été adressée.

25 Poonawala, Jurisprudence, 119-120. 
chercher et s'absorba dans la lecture d'autres ouvrages à tel point qu'il en eut mal aux pieds ${ }^{26}$. Cette bibliothèque s'enrichit encore plus sous les autres califes fātimides et nos sources fournissent bien des détails sur son contenu ${ }^{27}$.

Le paragraphe de notre épître cité plus haut décrit le précepteur détaillant aux fils du calife le contenu de l'Adab al-Kātib en élucidant ses problèmes. Nous sommes en présence de cette tradition d'éducation et d'érudition si chère à la discipline ismaélite à laquelle Halm a voué une recherche importante ${ }^{28}$. Le calife fățimide luimême est le maître, le mu'allim, par excellence : nous citons volontiers Daftary qui évoque «la doctrine de ta'lim qui met en relief l'éducation que chaque Imām inculque de sa propre autorité, indépendamment de celle de ses prédécesseurs $"{ }^{29}$. Dans ce contexte, l'on doit noter cette expression d'al-Qādīi al-Nu'mān citée plus haut: "Vous leur avez ouvert ce qui y était enfermé » (fatahta lahum muqfalahu). L'on peut percevoir ici le rôle du précepteur qui initie les disciples, les fils du calife, comme si, en leur inculquant le contenu de ce livre, il leur révélait des connaissances mystérieuses (bātin) recelées dans Adab al-Kātib afin qu'elles deviennent explicites (zāhir).

On peut se demander pour quelle raison le précepteur a choisi l'ouvrage $A d a b$ al-Kātib pour l'enseigner aux princes. Le fait qu'il a choisi précisément cet ouvrage spécialement démontre l'importance de l'œuvre d'Ibn Qutayba à ses yeux. Le Adab al-Kātib est en fait un manuel, peut être le premier qui a vu le jour, destiné à la formation des kuttāb, les fonctionnaires de l'Etat. Ibn Qutayba, qui était un kātib par sa formation, rédigea ce « manuel du parfait secrétaire $\gg{ }^{30}$ pour exposer la situation déplorable de l'administration et les défauts des secrétaires de son temps en expliquant comment y remédier ${ }^{31}$. Or il est bien possible que l'administration et les kuttāb de l'état fătimide en voie de formation aient souffert des mêmes imperfections qu'à l'époque d'Ibn Qutayba. Si Dhāt al-Bayān fut rédi-

26 Al-Qādī al-Nưmān, Majālis, 533, cité dans Halm, H., The Fatimids and their Traditions of Learning, London, 2001, 91.

${ }^{27}$ Halm, The Fatimids, 91-93.

28 Ibidem.

29 Daftary, F. (ed.), Medieval Isma'ili History and Thought, Cambridge, 2001.

${ }^{30}$ Lecomte, Introduction, 46.

31 Idem, Ibn Qutayba, 437-443 ; idem, Introduction, 46-49.

Al-Qanțara (AQ) XXXI 1, enero-junio 2010, pp. 77-102 ISSN 0211-3589 
gé pendant le règne d'al-Mu'izz comme nous le pensons, l'on remarque que c'est justement à cette période que le califat fătimide a fini par se stabiliser et qu'il a commencé à fonder son administration. En effet, c'est al-Mu izz qui « dota l'état d'une organisation administrative et financière rigoureuse » et «d'un système juridique et doctrinal homogène ${ }^{32}$. Il est donc naturel qu'un manuel pareil fût inculqué aux princes comme une étape de leur formation intellectuelle pour exceller à « la lecture correcte, l'orthographe et les dérivations » selon l'expression d'Ibn Qutayba, compte tenu du fait que l'un d'eux sera le futur calife, le successeur d'al-Mu'izz, donc l'administrateur suprême de l'état.

La recherche moderne a bien démontré la réputation de l'œuvre d'Ibn Qutayba et la manière dont il a été accueilli dès la fin du III/ IX siècle en Egypte, au Maghreb et en Andalousie ${ }^{33}$. En fait, les ouvrages d'Ibn Qutayba étaient couramment lus en Afrique du Nord, avec ceux d'Abū 'Ubayd al-Qāsim b. Sallām (m. 224/838) et de Jāhiz (m. 255/869) dès la fin du III siècle avant l'établissement du califat fătimide, à l'époque de la conquête entreprise par Abū 'Abd Allāh al-Shī' ${ }^{34}$. Déjà à cette époque les Shīites du Maghreb maudissaient Ibn Qutayba (lànat Allāh 'alā Ibn Qutayba) pour ses vues anti-shīites (táana 'alā l-Shîa ${ }^{35}$. Un peu plus tard, le secrétaire/vizir Abū Ja far, Muhammad b. Aḥmad al-Baghdādī introduisit les œuvres d'Ibn Qutayba, dont Adab al-Kātib, à la cour fătimide lorsqu'il arriva d'Orient au Maghreb avec le premier calife al-Mahdī, et il paraît que les califes et leurs entourages se plaisaient à les lire ainsi que celles de Jāhiz et d'autres lettrés orientaux ${ }^{36}$. Le Adab al-Kātib fut probablement introduit en Egypte par le fils d'Ibn Qutayba, Aḥmad b. 'Abd Allāh b. Muslim b. Qutayba (m. 322/933), qui fut nommé qā âi d'Egypte en 321/932 ${ }^{37}$. Cet ouvrage passa très tôt aussi au Maghreb et en Andalousie, entre autre par l'intermédiaire

32 Dachraoui, F., « al-Mu izz li-Dīn Allāh », EF.

${ }^{33}$ Lecomte, Ibn Qutayba, 12-14 et 19-23 ; Soravia, « Préface », 540-542.

${ }_{34}$ Madelung, W. et Walker, P., The Advent of the Fatimids, London, 2000, 115-116, 127 se référant au texte arabe d'Ibn al-Haytham dans ses Munāzarāt, 63, 73.

${ }_{35}$ Madelung et Walker, Advent, 143 se référant au texte arabe d'Ibn al-Haytham dans ses Munāzarāt, 94-95.

${ }^{36}$ Halm, H., The empire of the Mahdi : The Rise of the Fatimids, M. Bonner (trad.), Leiden 1996,169 et 369.

37 Lecomte, Ibn Qutayba, 13, 19.

Al-Qanțara (AQ) XXXI 1, enero-junio 2010, pp. 77-102 ISSN 0211-3589 
du célèbre Abū 'Alī al-Qālī (m. 356/967) qui l'avait probablement reçu d'Ahmad le fils d'Ibn Qutayba ${ }^{38}$. On note que sur le chemin de l'Andalousie vers l'an 329/940, dans les premières années du califat fătịmide, al-Qālī s'arrêta à Qayrawān où certains de ses livres furent perdus ${ }^{39}$, et Qayrawān, on le sait bien, est intimement liée aux Fātịmides en général et à al-Qāḍi al-Nu'mān en particulier ${ }^{40}$.

\subsubsection{Fols. 2a-2b : L'intervention d'al-Qāḍī al-Nưmān}

Jusqu'à ce moment de sa narration des évènements, al-Qāḍī alNu'mān n'est pas appelé à intervenir entre le précepteur et les princes. Cependant, son assistance en tant que docteur de la loi éminent est réclamée lorsque le précepteur doit aborder certaines des questions juridiques mentionnées dans Adab al-Kātib.

\footnotetext{
Vous avez abordé un chapitre de ce livre où il est question de certaines formules concernant des matières juridiques. Vous m'avez demandé des explications pour que vous puissiez leur (aux fils du calife) clarifier ces sujets parmi les différentes matières que vous avez expliquées et établies, ce que vous avez fait de votre propre connaissance. Vous avez lu ce chapitre devant moi (qara'ta 'alayya) et j'ai répondu à vos questions en expliquant son contenu et ses thèmes. Je vous ai fais remarquer ce qui y est digne de foi et ce qui ne l'est pas. Alors vous m'avez demandé d'exposer tout cela par écrit avec plus de détails dans un livre afin de mieux fonder le savoir, que le livre soit plus facile à commenter et soit plus à l'abri des ajouts et des lacunes. Je fus donc d'avis de l'écrire avec plus de détails comme vous me l'avez demandé afin qu'il devînt plus accessible et que les connaissances qu'il contient bénéficient aux princes...
}

Donc il est demandé à al-Qāḍī al-Nưmān, en sa capacité de docteur de la loi, de clarifier, oralement au début, ce paragraphe de l'introduction de Adab al-Kātib qui traite des formules juridiques citées par Ibn Qutayba. Le précepteur n'aurait donc pas été versé dans les questions de la loi. Par l'expression qara'ta 'alayya, « vous avez lu devant moi », l'on doit comprendre qu'al-Qādị al-Nu'mān devient le maître qui explique au précepteur les implications juridiques de ces

38 Ibidem, 13, 21 ; Soravia, "Préface ", 542-43.

${ }^{39}$ Sellheim, R., " al-Kāāî, Abū 'Alī Ismāēil b. al-Ḳāsim ”, $E I^{2}$.

40 Al-Qādī al-Nu'mān fit ses études à Qayrawān au début de l'insurrection fātimide et fut nommé juge de cette ville par le calife al-Manșūr en 337/948. Voir Dachraoui, F., " al-Nu'mān b. Abī 'Abd Allāh b. Manșūr b. Hayyūn ”, EI ${ }^{2}$; Hamdani, Between Revolution, 46-47.

Al-Qanțara (AQ) XXXI 1, enero-junio 2010, pp. 77-102 ISSN 0211-3589 
formules. Le précepteur ne s'en contente pas et demande au juge de rédiger ses explications en «termes plus détaillés » (basața) dans un livre, ce qui entraîne la rédaction de notre épître.

\subsubsection{Fols. 2b-3b : Les formules d' Ibn Qutayba}

Dans le paragraphe suivant de l'épître, al-Qādī al-Nưmān cite intégralement toutes les formules juridiques mentionnées par Ibn Qutayba $^{41}$, en déclarant qu'il avait l'intention de les traiter une à une dans son épître.

\subsubsection{Fols. 3b-4b : Les remontrances à Ibn Qutayba}

Ensuite, al-Qādī al-Nu'mān consacre un long chapitre où il commence à exposer ses remontrances à Ibn Qutayba. Ce chapitre est intitulé : «Les négligences d'Ibn Qutayba dans les propos qu'il a rédigés en termes détaillés dans le chapitre cité plus haut concernant les connaissances que le savant doit acquérir et s'imposer $»$.

Sachez, que Dieu vous prenne en Sa garde, que 'Abd Allāh b. Muslim b. Qutayba, quoique les savants de la langue arabe (ahl al-'ilm bi l-lisān) le considèrent fiable (thiqa) aussi bien à propos du savoir qu'il a transmis d'après les anciens que de la composition soignée de ce qu'il a recueilli et étudié, que néanmoins il est un des ennemis de Dieu et des Ses élus, l'adversaire et le détracteur acharné de la vérité et de ses détenteurs ; c'est un savant de «la lie du peuple» (hashwì), un Sunnite ('āmmî) qui croit en l'anthropomorphisme (tashbïh) et qui rejette l'Imamat de la famille du Prophète $<\mathrm{s}>$ tandis qu'il confirme l'Imamat de leurs ennemis à tel point qu'il surpasse à ce sujet la plupart des Sunnites. Il a même mentionné al-Husayn $\mathrm{b}$. 'Alī $<_{\mathrm{S}}>$ dans son livre qu'il a intitulé Kitāb al-Ma'ārif en disant : "Quant à Husayn il était prénommé Abū 'Abd Allāh. Il se révolta contre Yazīd, et 'Ubayd Allāh b. Ziyād dépêcha contre lui 'Amr b. Sa'd b. Abī Waqqāṣ, à la suite de quoi Sinān b. Qays le tua ». L'ennemi de Dieu Ibn Qutayba a donc classé ce al-Husayn parmi les rebelles (ou : les Khārijites, al-Khawārij) et le maudit Yazīd fils du damné Mu'āwiya parmi les Imāms. Telle est sa croyance et la croyance de ceux qui partagent ses opinions, comme on a rapporté que Mālik avait dit : «J'aurais préféré qu'il n'y eût pas de révolte contre Mu'āwiya ${ }^{42}$. Si je ne craignais pas que ce livre ne

${ }^{41}$ La comparaison entre le texte de Dhāt al-bayān et celui de Adab al-Kātib que nous possédons (M. al-Dālī (ed.), Beyrouth, 1986) révèle des différences insignifiantes qui pourraient résulter de fautes de copistes.

${ }^{42}$ Mā kuntu uhibbu-l-khurūj 'alā Mu'āwiya. L'on remarque qu'un copiste a ajouté d'une écriture différente l'expression «li $A l \bar{l} »$ après le verbe « uhibbu ». Nous commenterons cette glose plus bas.

Al-Qanțara (AQ) XXXI 1, enero-junio 2010, pp. 77-102 ISSN 0211-3589 
dépasse mes intentions, j'aurais cité les innombrables injures et agressions que l'ennemi de Dieu Ibn Qutayba a mentionnées dans ses livres contre les croyances des Imāms $<_{\mathrm{S}}>$ et leurs fidèles. Quiconque remarque ce qui est rapporté d'après lui concernant ce que Dieu a permis et interdit, Sa religion et Ses commandements, verra qu'il ne dit rien de véridique, que l'on ne peut pas se fier à lui ou apprendre quelque chose grâce à lui.

Par ces propos injurieux à l'extrême, al-Qādī al-Nu'mān tente de porter atteinte à la réputation et à l'intégrité d'Ibn Qutayba en tant que savant, ce qui démontre avant tout à quel point cette réputation était incontestable parmi les savants d'Orient et d'Occident à cette époque. Al-Qādī al-Nu'mān est forcé d'admettre la supériorité d'Ibn Qutayba dans les domaines « laïques», par conséquent il s'attaque à ses croyances religieuses. Quand il le traite de hashwī, il le critique en tant que savant « la lie du peuple», un de ceux « qui admettent le hadìth sans contrôle », signifiant par là qu'il ne trie pas les sources auxquelles il puise son savoir ${ }^{43}$. Il semble bien qu'al-Qādị al-Nu'mān préfère que ces sciences restent entre les mains des savants de son genre, pour lesquels le savoir doit venir seulement des Imāms de Ahl al-Bayt. En taxant Ibn Qutayba d'anthropomorphisme, al-Qādī al-Nu'mān se rallie à certains savants sunnites célèbres qui on fait de même. Pour al-Qāḍī al-Nu'mān et les bātiniyya, le problème épineux du tashbīh dans le Coran et dans le hadìth est résolu par l'interprétation allégorique ${ }^{44}$.

En traitant Ibn Qutayba «d'ennemi de Dieu et de Ses élus », il nous semble qu'al-Qāḍī al-Nu'mān fait allusion précisément aux attaques acharnées d'Ibn Qutayba contre les Rāfị̣ites extrémistes (ghulāt) et leurs revendications politiques et surtout contre les bātiniyya qui prétendent connaître le sens ésotérique du Coran ${ }^{45}$. L'on

${ }^{43}$ Lecomte, Ibn Qutayba, 336-337 ; "Hashwiyya”, EF. Il faut noter toutefois que certains savants associent les hashwiyya aux anthropomorphistes (al-mujassima). Voir Ibn 'Asākir, 'Alī b. Al-Hasan, Tabyīn Kadhib al-Muftarī fị mā Nusiba ilā-l-Imām Abī-lHasan al-Ashi arī, Beyrouth, 1404 H, 149-151. Voir aussi al-Shahrastānī, Muhammad b. Ábd al-Karīm, al-Milal wa-l-Nihal, M. Sayyid Kaylānī (ed.), Beyrouth, 1404 H, vol. 1, 105 : «Certains traditionnistes ḥashwiyya ont déclaré avoir des vues anthropomorphistes (sarrahū bi-1-tashbīh)».

${ }_{44}$ Lecomte, Ibn Qutayba, 328-329. Voir al-Dhahabī, Muhammad b. Ahmad, Siyar A'Tām al-Nubalā', S. al-Arnā'ūṭ (ed.), Beyrouth, 1992, vol. 13, 298-299 où Ibn Qutayba est aussi taxé de karrāmisme.

${ }^{45}$ Lecomte, Ibn Qutayba, 309-314 ; idem, Le Traité des Divergences du Hadīt d'Ibn Qutayba, Damas, 1962, 79-82.

Al-Qanțara (AQ) XXXI 1, enero-junio 2010, pp. 77-102 ISSN 0211-3589 
note que l'attitude d'Ibn Qutayba envers les Shīi ites non extrémistes est différente : il ne condamne pas la vénération modérée pour 'Alī mais n'accepte ni son infaillibilité et ni sa prééminence sur les autres Compagnons, notamment les trois premiers califes ${ }^{46}$.

La référence qu'al-Qāḍī al-Nu'mān cite d'après Kitāb al-Ma'ārif d'Ibn Qutayba est problématique. Nous proposons de mettre en parallèle le texte de notre épître et celui du Kitāb al-Ma'ārif tel que nous le possédons :

Le texte de Dhāt al-Bayān

Quant à Husayn il était prénommé Abū 'Abd Allāh. Il se révolta contre Yazīd (kharaja 'alā Yazīe), et 'Ubayd Allāh b. Ziyād dépêcha contre lui 'Amr b. Sa`d b. Abī Waqqāṣ, en conséquence Sinān b. Qays le tua ${ }^{47}$.
Le texte du Kitāb al-Ma'ārif

Quant à al-Ḥusayn b. ‘Alī b. Abī Țālib il était prénommé Abū 'Abd Allāh. Il sortit en direction de Kūfa (kharaja yurīd al-Küfa) et 'Ubayd Allāh b. Ziyād dépêcha contre lui 'Amr b. Sa'd b. Abī Waqqāṣ, en conséquence Sinān b. Abī Anas al-Nakhāì le tua ${ }^{48}$.

A la rigueur, nous pouvons attribuer la divergence concernant le nom du meurtrier d'al-Husayn à l'erreur d'un copiste de Dhāt alBayān car il nous semble qu'al-Qāḍ̄ al-Nu'mān, avec tout son savoir, ne pouvait pas ignorer le nom de Sinān $b$. Abī Anas al-Nakha ī et le remplacer par le nom d'un inconnu comme Sinān b. Qays. Le problème réside dans la divergence profonde entre l'expression d'Ibn Qutayba kharaja yurīd al-Kūfa et celle d'al-Qādī al-Nu'mān kharaja 'alā Yazìd. Même si l'on conçoit que le terme yurīd en Arabe peut être lu Yazìd (un simple point diacritique sur le $r$ qui devient $z$ ) il serait difficile d'expliquer la préposition 'alā ajoutée après le verbe kharaja, changeant ainsi le sens fondamental du verbe, et l'absence du terme Küfa dans le texte d'al-Qādī al-Nu'mān. Un premier argument pourrait être qu'al-Qādī al-Nu mān avait en main une version différente de celle que nous possédons du Kitāb al-Māārif. En effet, on peut comprendre que le texte de ce livre a été remanié plusieurs fois puisqu'il fut « conçu comme un manuel d'histoire auquel on aurait annexé toute une série d'appendices $»{ }^{49}$. Toutefois

${ }^{46}$ Lecomte, Ibn Qutayba, 315-317.

47 Al-Qādī al-Nưmān, Dhāt al-Bayān, fol. 4a.

48 Ibn Qutayba, 'Abd Allāh b. Muslim, al-Ma'ārif, T. 'Ukāsha (ed.), Le Caire, s. d., 213.

${ }^{49}$ Lecomte, Ibn Qutayba, 125.

Al-Qanțara (AQ) XXXI 1, enero-junio 2010, pp. 77-102 ISSN 0211-3589 
l'on note que 'Ukāsha qui publia le Kitāb al-Ma'ārif ne remarque pas de divergences concernant notre texte entre les divers manuscrits d'après lesquels il établi la version que nous possédons ${ }^{50}$. Un autre argument serait qu'al-Qāḍ̄ al-Nu'mān ou l'un des transmetteurs ultérieurs de Dhāt al-Bayān avait modifié intentionnellement le texte d'Ibn Qutayba dans le but de «démontrer »son hostilité profonde envers les Ahl al-Bayt.

Al-Qāọī al-Nu'mān raisonne à la suite qu'Ibn Qutayba n'est pas le seul savant à avoir considéré les Imāms de la famille du Prophète comme rebelles et leurs ennemis comme des califes légitimes. Il rapporte dans ce contexte une expression attribuée à Mālik b. Anas (m. 179/795) selon laquelle il désapprouve les révoltes contre Mu'āwiya (al-khurūj 'alā Mu'āwiya). Or dans notre manuscrit on a rajouté d'une écriture différente le terme «li 'Alī» après le verbe «uhibbu» et ainsi l'expression de Mālik devient: mā kuntu uhibbu li 'Alī l-khurūj 'alā Mu'āwiya, ce qui veut dire: "J'aurais préféré que ‘Alī ne se révoltât pas contre Mueāwiya ». Nous n'avons trouvé aucune de ces deux expressions dans les sources que nous avons consultées, ni sunnites ni shi'ites. Cependant, l'on attribue à Mālik b. Anas l'expression selon laquelle « la sortie de 'Alī (de Médine contre ses ennemis lors de la bataille du Chameau) fut une erreur » (kāna khurūj 'Alī khața'an $)^{51}$. Il est donc possible qu'al-Qādī al-Nu'mān ait cité Mālik d'après une source pro-umayyade quelconque. N'ayant qu'un seul manuscrit à notre disposition, nous ne pouvons pas déterminer si la glose $l i{ }^{\prime} A l i ̄$ dans cette expression est tardive ou bien si elle existait déjà dans le texte original d'al-Qādī al-Nu'mān. L'on note cependant que les savants mālikites du Maghreb au début de la conquête fātimide étaient nettement proumayyades et exprimaient des opinions qui reflétaient clairement l'expression attribuée à Mālik. Deux d'entre eux furent même exécutés pour avoir affirmé «la prééminence de Mu'āwiya sur le seigneur des hommes (i.e. 'Alī)» (faḍl Mu'āwiya 'alā sayyid al-bas$\left.h a r^{52}\right)$ et que «'Alī n'avait pas le droit de revendiquer le califat et

${ }^{50}$ Ibn Qutayba, ‘Abd Allāh b. Muslim, al-Ma'ārif, Th. 'Ukāsha (ed.), Le Caire, s. d., "Introduction ", 82-100.

${ }^{51}$ Ibn Habīb, 'Abd al-Malik, Kitāb al-Ta'rīkh, J. Aguadé (ed.), Madrid, 1991, 115.

52 En général, c'est le Prophète qui est nommé sayyid al-bashar. Toutefois, certaines traditions shī'ites attribuent cette appellation à 'Alī. Voir al-Shaykh al-Mufīd, al-Irshād, 35 ('Alī sayyid al-bashar lā yashukku fỉhi illā kāfir, selon une tradition transmise d'après 
par conséquent il n'aurait pas dû faire la guerre contre Mu'āwiya » (wa-anna 'Aliyyan $<_{S}>$ kharaja ilā harb Mu'āwiya watalaba l-imāra wa-anna tālib al-imāra lā haqq lahu alā l-matlub) ${ }^{53}$. Ainsi, l'expression attribuée à Mālik dans notre épître est reprise par certains savant mālikites plus tard et laisse entendre que Mu'āwiya est un calife légitime tandis que ses ennemis, les Imāms de la famille du Prophète inclus, sont des rebelles. C'est ce qu'alQādī al-Nưmān voulait démontrer.

La remarque d'al-Qāḍi al-Nu'mān concernant Ibn Qutayba à la fin de ce paragraphe selon laquelle «l'on ne peut pas se fier à lui ou apprendre quelque chose grâce à lui » est peut-être adressée au précepteur et pourrait refléter l'objection de notre auteur contre le fait qu'il a choisi le Adab al-Kātib pour l'inculquer aux princes.

\subsubsection{Fols. 4b-7a : L'importance des dissertations des juristes}

Al-Qādī al-Nu'mān arrive enfin au sujet qui compte le plus pour lui et qui a motivé la rédaction de l'épître : les devoirs du faqīh et l'importance de ses fonctions comme interprète de la loi de la communauté. Ibn Qutayba affirma :

«Il lui faut (au fonctionnaire) en outre, la connaissance théorique des énoncés du fiqh et une connaissance technique des fondements (usūit) de la tradition de l'Envoyé de Dieu et de ses compagnons $\langle$ s $\rangle$ ». Ensuite il mentionna ces formules que nous avons citées plus haut après avoir exposé plusieurs sciences qu'il exhorta les fonctionnaires à connaître et qu'il leur enjoignit d'étudier. En ce qui concerne les sciences du fiqh il se restreignit à aux formules qu'il avait mentionnées, sous prétexte qu'elles dispenseront le savant « des longues dissertations des juristes » (itālat al-fuqahā') ${ }^{54}$. Ses propos traduisent son ignorance, son manque d'inclination et sa réticence en ce qui concerne le fiqh. Il aurait mieux fait de placer le fiqh en tête des sujets qu'il exhorta les fonctionnaires à connaître et de leur enjoindre d'étudier ce que Dieu requiert aux croyants de savoir afin qu'ils puissent appliquer les lois que Sa religion leur impose, au lieu de les restreindre à la connaissance de ces formules succinctes en prétendant qu'elles les dispenseront d'en connaître d'autres. Après l'affirmation de

l'autorité de Jābir b. 'Abd Allāh). Voir aussi Idrīs, 'Uyūn, vol. 6, 288-292, où l'auteur consacre une longue discussion pour légitimer le fait que 'Alī devait être nommé khayr al-bashar...

${ }^{53}$ Madelung et Walker, Advent, 30, se référant au texte arabe d'Ibn al-Haytham dans ses Munāzarāt, 118.

${ }^{54}$ Nous devons à Soravia et à Lecomte la traduction des passages entre guillemets. Voir Lecomte, "Introduction ”, 60 ; Soravia, « Préface”, 557.

Al-Qanțara (AQ) XXXI 1, enero-junio 2010, pp. 77-102 ISSN 0211-3589 
l'Unification de Dieu et la connaissance de Ses élus qui entraînent la soumission des fidèles aux actes de dévotion, il aurait dû les exhorter aux devoirs de la purification, de la prière, de l'aumône, du jeûne, du pèlerinage et du jihād car ceux-ci sont les piliers sur lesquels l'Islam repose (da'à'im al-Islām allatī buniya 'alayhā).

Ce qui provoque la réaction de notre auteur, c'est surtout l'assertion d'Ibn Qutayba selon laquelle la connaissance de formules juridiques succinctes par cœur est suffisante et dispense les fonctionnaires des « verbiages » des docteurs de la loi. Al-Qāḍi al-Nu mān s'acharne à expliquer que c'est justement ces « verbiages » qui sont les plus nécessaires pour pouvoir appliquer correctement la Loi de Dieu. Nous pouvons arguer que l'assertion d'Ibn Qutayba rendrait superflue la fonction du faqīh en général et celle d'al-Qāḍī alNu'mān en particulier. Si notre hypothèse est correcte et que notre épître fut en effet rédigée durant le règne d'al-Mu'izz, al-Qāḍ̄i alNu'mān était à cette période à l'apogée de sa fonction de qădịi, il était le docteur de la loi et l'auteur le plus important, le seul dironsnous, des travaux juridiques du califat fātimīde. Il est donc compréhensible qu'il ait voulu réfuter Ibn Qutayba, surtout au sujet de cette expression.

Al-Qādīi al-Nu'mān énonce un à un dans ce paragraphe les « sept piliers de l'Islam » qui furent à la base de la composition de son fameux compendium juridique, le Da'ä'im al-Islām ${ }^{55}$. On peut concevoir que si cet ouvrage avait été composé antérieurement à notre épître, l'auteur l'aurait mentionné très probablement dans ce paragraphe de Dhāt al-Bayān.

Ensuite al-Qāḍī al-Nu mān discute longuement de la nécessité du savoir ('ilm) et il affirme que les dissertations des fuqahā' constituent toutes un savoir indispensable. Il cite la tradition connue du Prophète selon laquelle chaque Musulman et chaque Musulmane sont requis de rechercher le savoir (talab al-'ilm). Par la suite il discute des devoirs de la prière, de la purification et du jeûne, en insistant sur le fait que l'on devrait les inculquer aux enfants, même de force. Il se réfère dans ce contexte à des traditions qu'il cite d'après le Prophète, 'Alī, Muhammad al-Bāqir et Ja'far al-Ṣādiq.

${ }_{55}$ Pour les « sept piliers de l'Islām », voir Halm, The Empire, 370-374.

Al-Qanțara (AQ) XXXI 1, enero-junio 2010, pp. 77-102 ISSN 0211-3589 
Et al-Qāḍi al-Nu'mān revient à l'assertion d'Ibn Qutayba pour la réfuter de nouveau :

Les longues dissertations des fuqahā' sont toutes du savoir (tatwil al-fuqahā' 'ilm kulluhu), et celui qui prétend pouvoir s'en dispenser ne connaît pas la valeur du savoir et ignore le savoir. Quelle honte pour celui qui connaît apparemment ces formules qu'Ibn Qutayba a mentionnées et qui prétend qu'elles l'exemptent d'une connaissance plus générale, et lorsqu'il se purifie et se lave ou se frotte avec du sable (tayammam), il s'avère qu'il ne sait ni comment se purifier, ni se laver ni se frotter avec le sable. Ou bien il prie et ne sait pas comment ou alors on lui pose une question concernant sa foi et il ne sait pas quoi répondre.

Al-Qādị al-Nu'mān cite en exemple une tradition très peu connue selon laquelle pendant que les Musulmans étaient en chemin vers une razzia (ghazwa), on raconta au Prophète que 'Ammār b. Yāsir avait été aperçu en train de se vautrer nu dans le sable (yatama"ak "uryān fí l-turāb). Muhammad lui demanda pourquoi il se vautrait comme le ferait un âne (kamā yatama"ak al-himār) et 'Ammār répondit qu'il voulait se purifier avec du sable parce qu'il ne trouvait pas d'eau. Muhammad se mit à rire et enseigna à 'Ammār comment faire le tayammum ${ }^{56}$. Al-Qādī al-Nu'mān ajoute qu'il aurait suffi à 'Ammār de consulter le Coran à ce sujet. Et il continue à fustiger Ibn Qutayba :

De même les imāms d'Ibn Qutayba, cet ignorant, se sont trompés sur bon nombre de questions juridiques et ont rendu plusieurs jugements erronés concernant le licite et l'illicite (al-ḥalāl wa-l-harām); il en est de même pour ses compagnons qui professent sa doctrine et pour beaucoup d'autres qui ne se sont pas appliqués à la connaissance de la jurisprudence et se sont limités au savoir auquel il les exhorta en prétendant que cela leur suffirait. Tel Abū Bakr qui ordonna de trancher la main d'un invité qui avait volé alors que l'on ne tranche pas la main d'un invité, ou bien 'Umar qui ordonna de lapider une femme enceinte qui avait commis l'adultère alors qu'une femme enceinte ne doit pas être lapidée tant qu'elle n'a pas accouché. De tels exemples sont trop nombreux pour que nous puissions les citer ici et dépassent les limites de notre livre. De tels exemples sont rapportés d'après ces gens-là et nous avons-nous même été témoins maintenant d'exemples similaires concernant des (disciples) illustres d'Ibn Qutayba.

${ }^{56}$ L'épisode tel qu'al-Qāḍi al-Nu 'mān le cite n'est pas mentionné dans les sources à notre disposition, tant shīites que sunnites. Pour une version différente de cet épisode voir al-Ṭabarānī, Sulaymān b. Ahmad, al-Mu’jam al-Awsaț, Țāriq 'Awậ Allāh et 'Abd al-Ḥasan b. Ibrāhīm (eds.), Beyrouth, 1995, vol. 2, 13.

Al-Qanțara (AQ) XXXI 1, enero-junio 2010, pp. 77-102 ISSN 0211-3589 


\subsubsection{Fols. 7a-8b : La réfutation des Mālikites}

Bien qu'il affirme que ce n'était pas nécessaire, al-Qādī alNu'mān s'acharne à fournir d'autres exemples de juristes de son époque qui, comme Ibn Qutayba, ne connaissaient pas les subtilités de la loi et se contentaient de formules juridiques traditionnelles. Il nous semble qu'al-Qāḍ̄ al-Nu'mān s'en prend surtout au Mālikisme puisqu'il cite plusieurs exemples concernant l'ignorance des docteurs mālikites de son temps en matière de juridiction.

Ainsi il raconte qu'Abū 'Abd Allāh, le grand maître de la da'wa du Maghreb (șăhib da'wat al-Maghrib) avait demandé à un juriste mālikite de Qayrawān sur quoi il se fondait en appliquant la loi et il répondit qu'il se fondait sur la Sunna. Abū 'Abd Allāh lui demanda de lui expliquer la Sunna et le juriste répondit : « Le Coran est la parole de Dieu incréée » (al-Qur'ān kalām Allāh ghayr makhlūq). Ce juriste fut la risée de toutes les personnes présentes affirme al-Qādī al-Nu 'mān. Nous n'avons pas trouvé cet épisode dans les sources à notre disposition. Toutefois, les débats polémiques sur le dogme en général et sur la Sunna en particulier, et à Qayrawān précisément, entre Abū 'Abd Allāh al-Shīî̀ et son frère Abū l-'Abbās d'une part et les juristes mālikites d'autre part, sont bien attestés dans les sour$\operatorname{ces}^{57}$.

Bien que cet épisode ait été ridiculisé par al-Qāḍ̄i al-Nưmān, il se fonde néanmoins sur la controverse qui opposait à cette époque les Mālikites et les Hanafites pro-mu'tazilites de Qayrawān. Les Muetazilites étaient d'opinion que le Coran a été « créé » (makhlūq) tandis que les Mālikites préconisaient 1'opinion contraire ${ }^{58}$. Il est donc logique que la réponse du juriste mālikite concernant la Sunna, (de son point de vue personnel), soit correcte dans cette perspective qui était la sienne.

Al-Qādị al-Nu 'mān rapporte ensuite qu'un autre docteur de la loi mālikite entreprit de critiquer les juristes hanafites (al-'Irāqiyyūn $)^{59}$. Un autre juriste qui savait combien le Mālikite était ignorant lui demanda quel était le montant de l'aumône qu'on devait payer quand on gagnait la somme de deux cents dirhams. Après réflexion, le

\footnotetext{
${ }^{57}$ Halm, The Empire, 240-247.

${ }^{58}$ Sur cette controverse à cette époque voir Madelung et Walker, Advent, 20-23.

${ }^{59} \mathrm{Au}$ sujet de cette expression, voir id., 21.
} 
Mālikite répondit qu'on devait payer deux dirhams. On le ridiculisa en remarquant que son ignorance concernant l'aumône aurait du l'empêcher de critiquer les savants.

Un troisième savant mālikite fut nommé à la fonction de juge par un autre juge (istahkamahu ba'ḍ l-qud̄āt). Ce dernier demanda un jour au Mālikite ce qu'il avait jugé pendant cette journée et il répondit qu'il avait rendu une sentence contre un absent (ghä'ib). Le juge le félicita en lui disant que son verdict était conforme à la Sunna (așabta 1-Sunna). Puis il lui demanda à quelle place se trouvait l'absent et le Mālikite mentionna un lieu qui se trouvait à peu près à deux milles (qadr mîlayn). Le juge s'écria : «Malheureux, tu nous as couvert de honte. On ne rend pas un verdict contre un absent qui se trouve dans un lieu si proche $»$.

Enfin, al-Qādī al-Nu mān donne un exemple concernant un notable, descendant de la famille du Prophète (ba'd ahl al-nasab alsharīf), à qui on fit honneur en l'invitant à réciter la prière des morts pour un décédé. Le notable (se trouva dans une position où il) ne pouvait pas refuser et pourtant il ne savait pas comment faire la prière. Il entreprit de réciter la prière habituelle. Quand on réalisa son ignorance, on le ridiculisa et un savant fit la prière en mémoire du défunt selon les usages.

Al-Qāḍī al-Nưmān termine son introduction en résumant :

Donc, le premier savoir à acquérir c'est la connaissance de ce qui est indispensable dans le domaine du fiqh et de ce qui est nécessaire pour pouvoir exercer les actes de dévotions. Après quoi tout autre savoir que l'étudiant acquiert l'enrichit et l'honore encore plus. Dieu a dit : "Allāh élévera en degrés ceux d'entre vous qui auront cru et ceux qui auront reçu le savoir » (Sourate 58, verset 11). Et aussi : « Sont-ils égaux, ceux qui savent et ceux qui ne savent pas ? Seuls les doués d'intelligence se rappellent» (Sourate 39, verset 9). Et 'Alī $<$ s $>$ à dit: «la valeur de chaque personne réside dans ce qu'il sait faire $\gg{ }^{60}$.

C'est ainsi que se termine l'introduction de l'épître et que commence l'exposition des formules juridiques citées par Ibn Qutayba accompagnées des commentaires d'al-Qādịi al-Nu mān.

${ }^{60}$ Al-Majlisī, Muhammad Bāqir, Biḥār al-Anwār al-Jāmi' a li-Durar Akhbār al-A'imma-1-Ațār, Beyrouth, 1983, 165-166.

Al-Qanțara (AQ) XXXI 1, enero-junio 2010, pp. 77-102 ISSN 0211-3589 


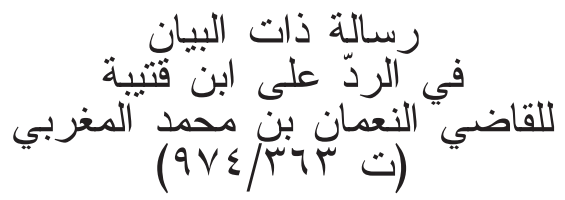

61 [مقدمة المؤلف]

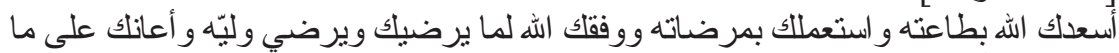
استكفاك و أقامك له اله كنت أحضرنتي، و أحضرك الله التوفيق، كتاب عبد الله بن مسلم بن قتيبة الذي ألفه في ثقويم

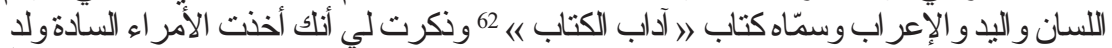

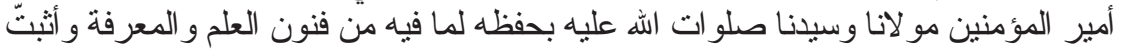

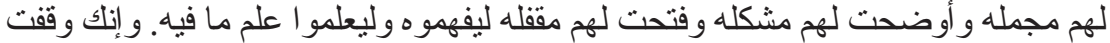

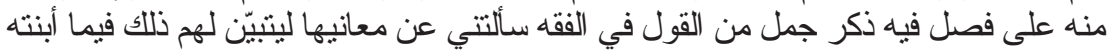

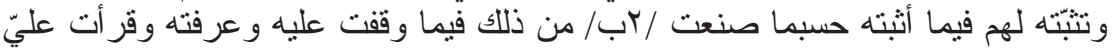

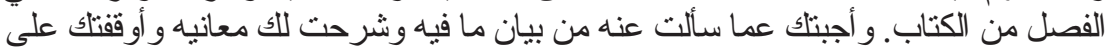

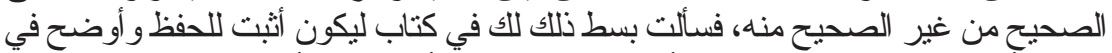

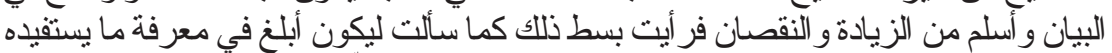

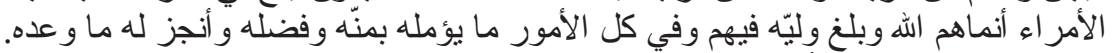
ا ـ ذكر الفصل الذي سألت بيان ما فيه فيه وفيه أثبتث ما في هذا الفصل أوّلا على حسبما هو في الكتاب المُقَّمّ ذكره ليكون البيان على فصوله فصلا فصلا إنشاء الله. ذكر ابن قتيبة في هذا الكتاب ما ينبغي لطالب العلم و الأدب أن يعلمه ويأخذ نفسه بحفظه

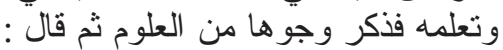

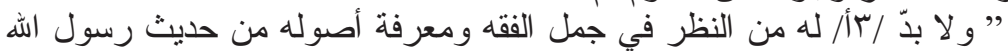
صلى الله عليه و على آله

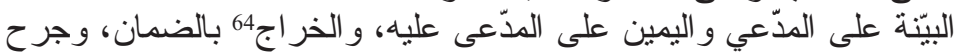

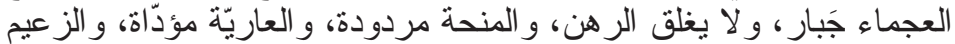

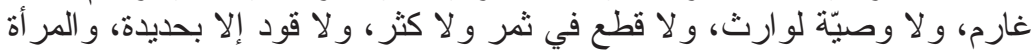

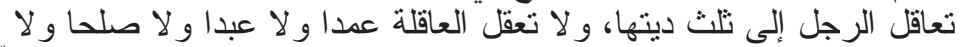

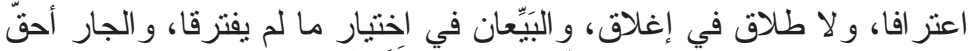

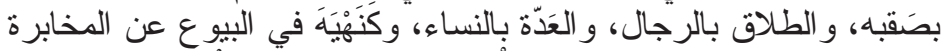

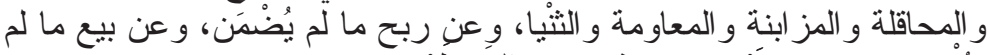

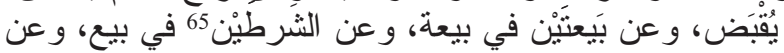

61 في الهامش وبخط مغاير للأصل : بسم اله الرحمن الرحيم. الحمد لله رب العالمين وصلى اله على سيدنا

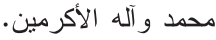

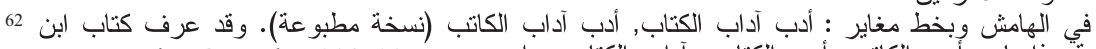

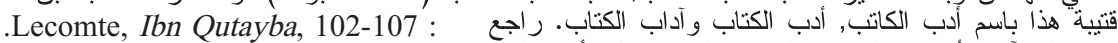

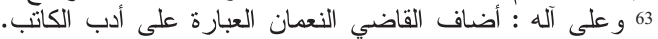
64 كتب فوقها بخط مغاير : ألخرج. 65 في أدب الكاتب : شرطين. 


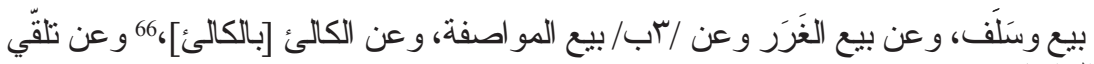

الركبان. r. البيان على 68 ذكر إغفال ابن قتيبة فيما بسطه قبل هذا الفصل مما ذكره أنه ينبغي لطالب العلم أن يعلمه ويأخذ بـ نانه نفسه.

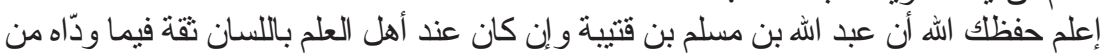

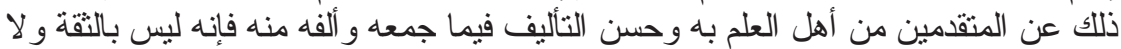

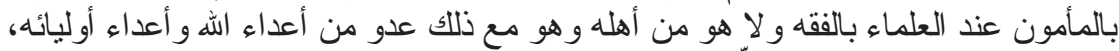

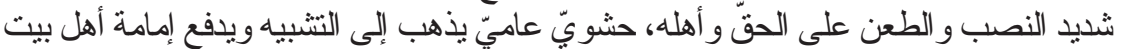

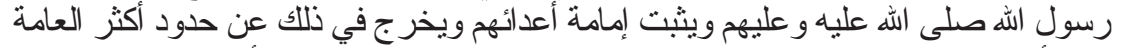

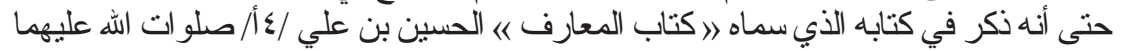
فقال : و أما حسين فكان يكنى أبا عبد الله وخرج على يزيد فوجه إلبه عبيه عبيد الله بن زياد

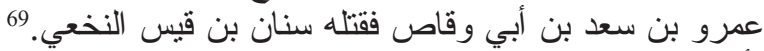

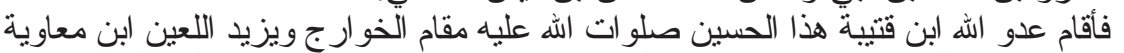

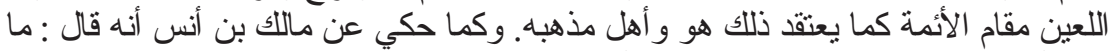

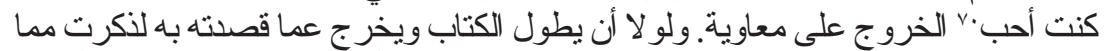

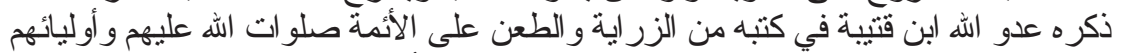

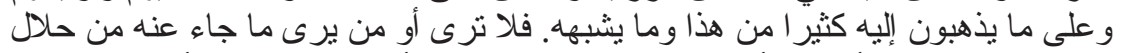

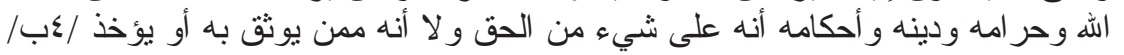

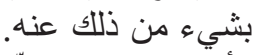
و أمَاً قوله : إو لاء بدّ من النظر في جمل الفقه ومعرفة أصوله من حديث رسول الله صلى الله

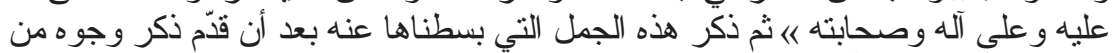

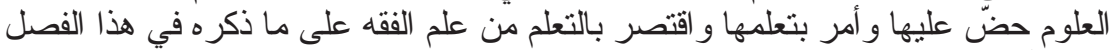

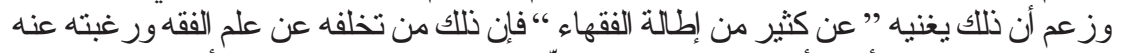

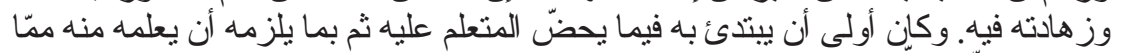

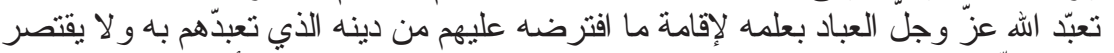

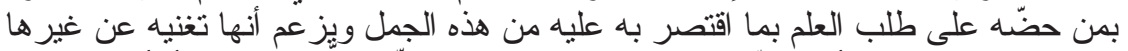

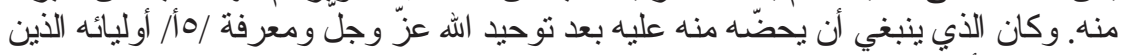

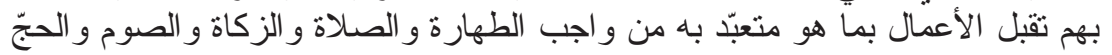

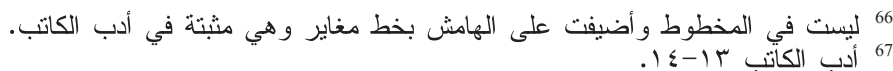

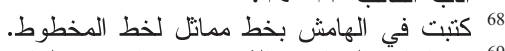

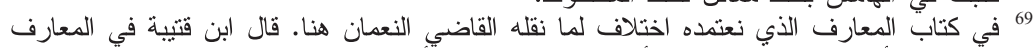

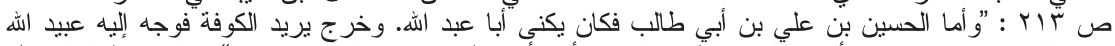

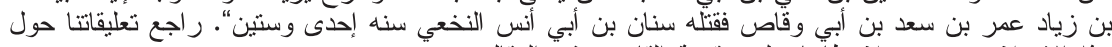

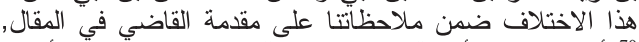

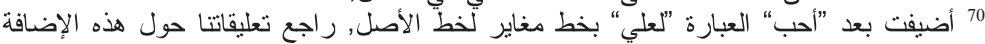
ضمن ملاحظاتتا على مقدمة القاضي في لعي" المقال, 


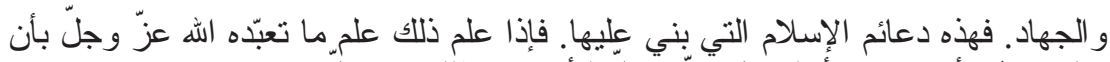

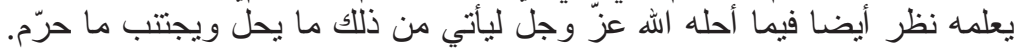

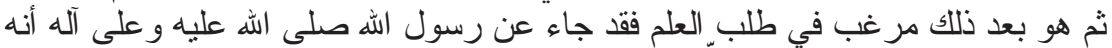

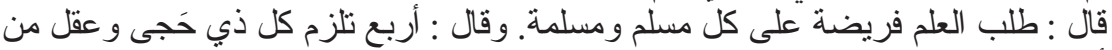

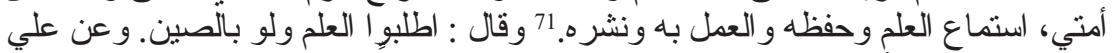

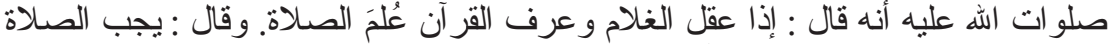

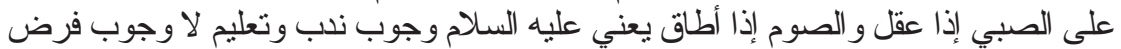

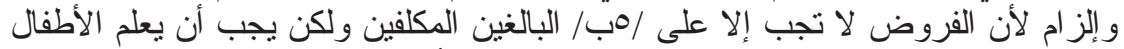

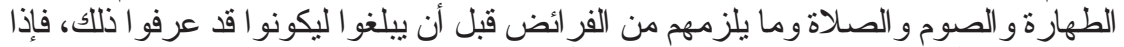

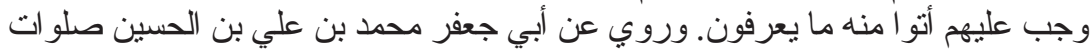

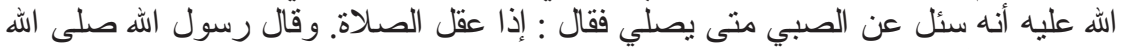

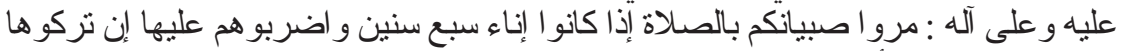

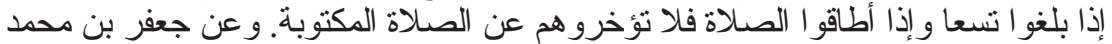

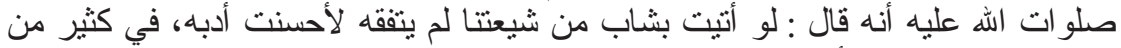

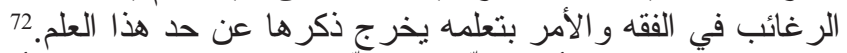
فكان ينبخي لابن قتيبة أن يحضّ من حضّهـ

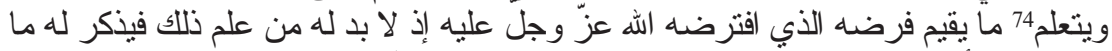

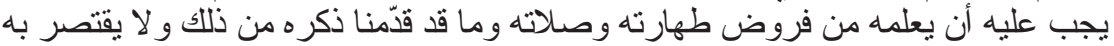

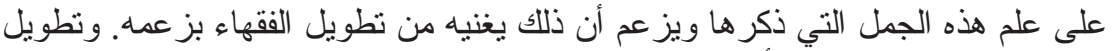

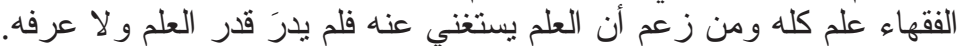

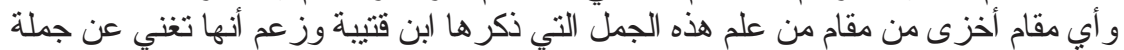

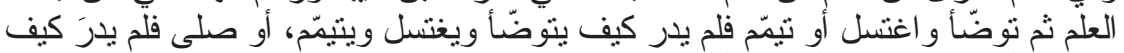

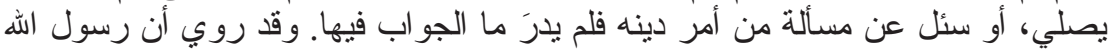

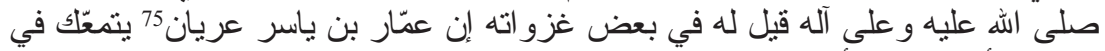

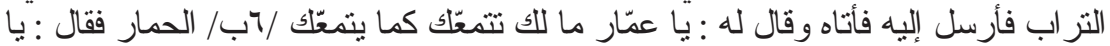

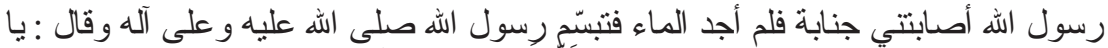

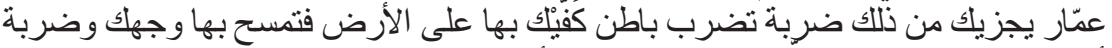

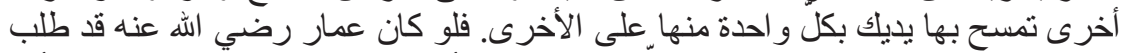

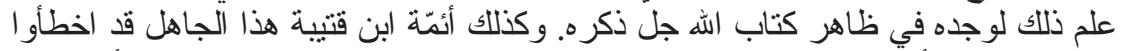

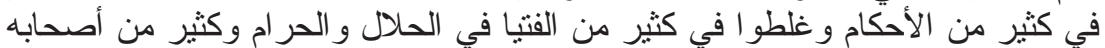

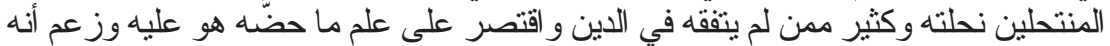

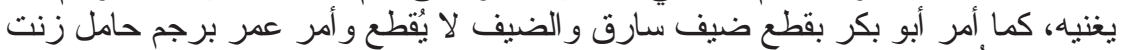

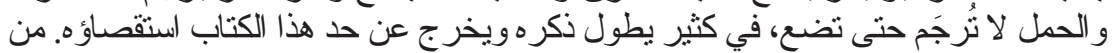

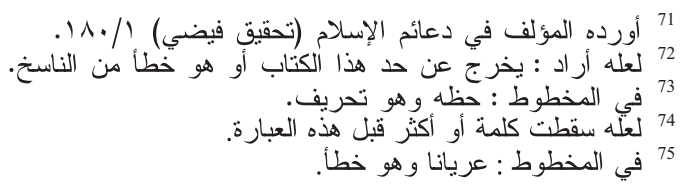

Al-Qanțara (AQ) XXXI 1, enero-junio 2010, pp. 77-102 ISSN 0211-3589 
منل ذلك ما جاء عنهم وكمثل ما بلغنا وشاهدناه من أهل عصرنا من جلة

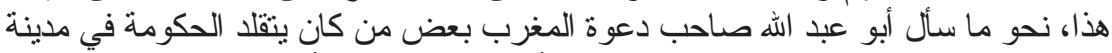

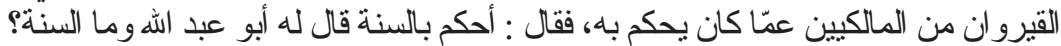

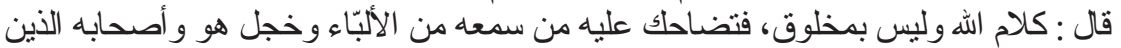

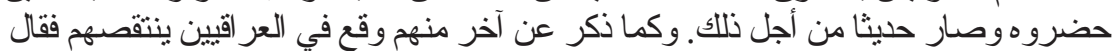

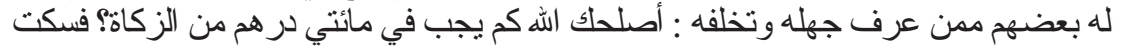

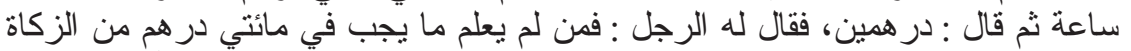

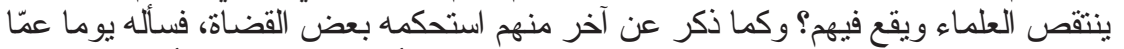

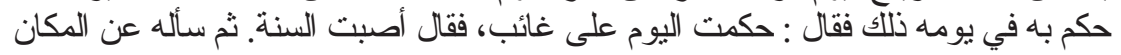

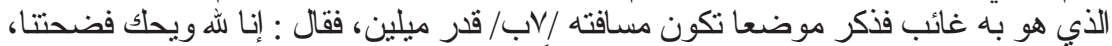

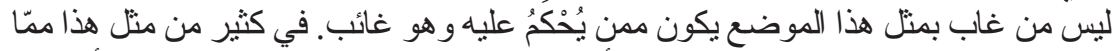

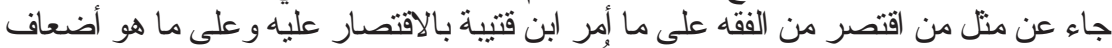

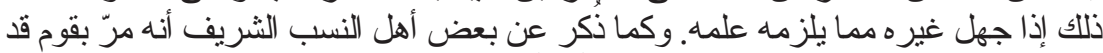

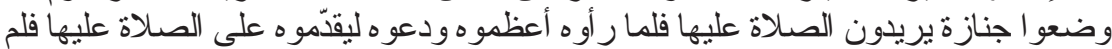

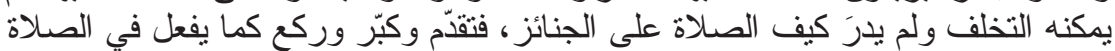

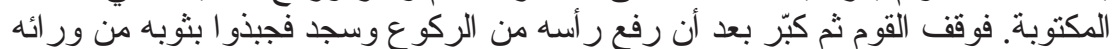

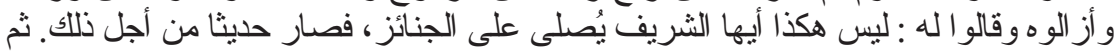

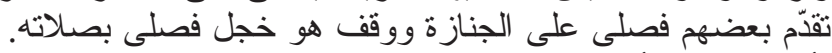

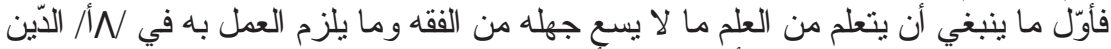

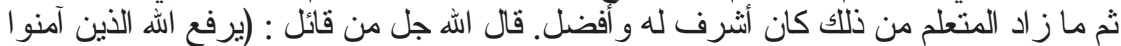

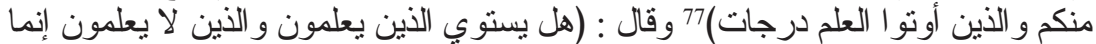
يتذكر أولو الألباب).78 وقال علي صلو ات الله عليه : قيمة كل امرئ ما كان بحسن.

Recibido : 08/02/2008

Aceptado : 24/06/2009 